\title{
Histopathological changes induced by ergasilid copepod infections on the gills of food fish from Batticaloa lagoon, Sri Lanka
}

\author{
P. VINOBABA* \\ Department of Zoology, Eastern University, V antharumoolai, Chenkalady, \\ Sri Lanka \\ *E-mail: vinobaba@esn.ac.lk
}

\begin{abstract}
Histopathological changes induced by ergasilid parasitic infections on the gills of economically important fish from Batticaloa lagoon were investigated from October 2003 to November 2004. Anabas sp, Ambassis gymnocephalus, Chanos chanos, Cirrhinus mrigala, Etroplus suratensis, E. maculatus, Hemirhamphus sp, Leiognathus splendens, Lutjanus sp, Mugil cephalus, Nematalosa nasus, Oreochromis mossambicus, Siganus lineatus, S. oramin, Tachysurus sp, Terapon jarbua and Triacanthus brevirostris were naturally infected with the ergasilids viz.Ergasilus sieboldi, E. parvitergum, and Dermoergasilus sp. Intensity of infection ranged from 0 to 30 ergasilids per host fish. Histopathological investigations of infected gills showed extensive tissue damage due to attachment and feeding of ergaslids. Ergasilus sp attached close to the base of the filaments near the gill arch and the pressure exerted by the parasite attached to the lateral margin of the gill filaments induced atrophy of the secondary lamellae. Tissue reactions included hyperplasia and mucous cell proliferation of the gill epithelium and damaged primary and secondary lamellae. In addition, considerably high numbers of eosinophilic granular cells and rodlet cells were noticed in the gills of the infected fish. Histopathological changes induced by the ergasilid infections would adversely affect the proper functioning of the gills of these host fish. Mass mortalities of the fish inhabiting Batticaloa lagoon which occurred during April and May 2004 may be attributed to the infection of the fish gills by these ergasilids.
\end{abstract}




\section{Introduction}

Parasitic copepods are common on cultured and wild finfish, and there is a vast literature available for the taxonomy and host ranges. Many of these species have long been recognized to have the potential to affect the growth, fecundity and survival of hosts (White 1940; Kabata 1958; Hewitt 1971; Neilson et al. 1987 and Johnson et al. 1996). Along with the developments in semi-intensive and intensive brackish water and marine aquaculture, the importance of parasitic copepods as disease causing agents has become more obvious.

Different Ergasilus species have been described from different hosts and locations in Brazil (Motta_Amado and Rocha, 1995), while in EuropeE. sieboldi has been recorded in 14 species of British freshwater fishes (Alston and Lewis 1994). In gills of Tinca tinca infected by E. sieboldi, haemorrhages and inflammation were accompanied by reactive granulocytosis connected with intensified hemopoiesis and also an accelerated process of destruction of these cells in the peripheral blood (Alston and Lewis 1994). Moreover, extensive tissue damage resulting from the feeding and attachment ofErgasilus sp. was reported in several species of fishes (Abdelhalim 1990). In addition, it was suggested that lesions due to attachment and feeding of ergasilids may be secondarily infected with fungi, bacteria and viruses (Nigrelli 1950; Dogiel 1958). Lamellar fusion due to the hyperplasia of the interlamellar epithelium, massive mucous cell proliferation as well as the occurrence of a high number of eosinophilic granular cells (EGCs) and rodlet cells (RCs) in gills of fish infected withErgasilus sp were recorded. In Canada Ergasilus labracis was found to be responsible for the death of a large number of Atlantic salmon,Salmo salar, parr over a 4-day period in New Brunswick (Hogans 1989). In Sri Lanka, preliminary parasitic surveys on a range of economically important marine and freshwater fish species conducted by some workers recorded a number ofErgasilus species (Nilakarawasam and Sommerville 1998; Rahuman and Vinobaba 1999), however their histopathological impact on their hosts from lagoon environments remains to be determined. The aim of the present study was to study the host-parasite interaction with specific reference to the pathology induced by ergasilid parasites on economically important food fish inhabiting in Batticaloa lagoon.

\section{Materials and Methods}

The fish were captured by cast net and hook and line from the Batticaloa lagoon and kept alive in lagoon water. After capture, live fish left in the same water were transported to the laboratory where the fish were anesthetized in benzocaine and killed instantly. The gills were removed from the sacrificed fish and microscopic examination was carried out under the 
dissecting microscope, to count the number of parasites on the gills. The Ergaslius sp were mounted on glass slides and the flat preparations were made for the identification. Identification was primarily based on the number of the segments of antennae, antennules, urostyle, and length width ratio (Fryer 1982; Kabata 1979; Ho and Do 1982). Prevalence of parasites and intensity of infection for each fish species were determined as described by Margolis et al. (1982).

For histological studies, the infected gills were placed immediately in $4 \%$ buffered formalin. Formalin fixed gills were processed for histological sectioning in an auto processor and thin sections $(5 \mu \mathrm{m})$ were taken using a microtome. The sections were stained with eosin and haematoxylin. Histopathology in the gills was studied under a binocular light microscope.

\section{Results}

A wide variety of fin fish species were found to be infected with several species of ergasilids viz. E. parvitergum, E. sieboldi and Dermoergasilus sp. The list of hosts and corresponding parasite species are given in the Table 1. Co-habitation of differentErgaslius sp is also noticed in this study. The prevalence and intensity of infection varied with the host fish species studied (Tables $2,3 \& 4$ ).

Adult females of ergasilids attached to primary lamellae (gill filaments) of the host fish with their claw-like second antennae close to the gill arch near the base of the filaments (Figure 1). The parasite's body rests between the hemibranchs with the axis parallel to the primary lamellae axis and with its cephalic extremity oriented towards the gill arch.

Females of Ergasilus sieboldi (Figure 1) are violin shaped, with lateral constriction in posterior half, depressed dorso-ventrally. Second to fifth legs bearing segments are narrower than the first cephalothorax segment. Abdomen is three segmented, equal to the size of the genital complex. Uropod is half of the size of abdomen. First antennae is six segmented. First segment has three setae, second eleven setae, third five setae, fourth four, fifth three and sixth six setae. Second antennae is with short, robust first segment and longer second segment. Sympods of four swimming legs are two segmented.

In Ergaslius parvitergum, the cephalothorax is distinctly inflated and breadth is two third of the length. Metasomal somites are abruptly narrowed from cephalothorax, decreasing in size towards the posterior end. Fourth pedigerous somite is extremely reduced, equal to the size of the fifth. Genital segment is considerably larger than other segments, egg sacs approximately two times of the length of the body. Antennule is six segmented and the numbers of setae on segments are 3,10, 4, 3, 2 and 7 respectively. Antenna has three segments and the terminal claw is strongly curved. Swimming legs are present in pairs, 1-4 biramous, rami three segmented except fourth 
exopod with two segments. Leg 5 is reduced to small process with one seta. Caudal rami with very long seta.

Table 1. The species compositions ofErgasilus sp found in the fish sampled from Batticaloa lagoon.

\begin{tabular}{ll}
\hline \multicolumn{1}{c}{ Host * } & \multicolumn{1}{c}{ Parasites } \\
\hline Anabas (21) & E.parvitergum, E.sieboldi, Dermoergasilus sp \\
Ambassis gymnocephalus (16) & E. parvitergum, E.sieboldi \\
Chanos chanos (30) & E. parvitergum, E.sieboldi, Dermoergasilus sp \\
Etroplus suratensis (99) & E.parvitergum, E.sieboldi, E. parvitergum \\
E. maculatus (39) & E. parvitergum, E.sieboldi, \\
Hemirhamphus sp (15) & E. sieboldi, E. parvitergum \\
Leiognathus splendens (29) & E. parvitergum, E.sieboldi \\
Lutjanus sp (31) & E. parvitergum, E.sieboldi \\
Mugil cephalus (35) & E. parvitergum, E.sieboldi \\
Nematalosa nasus (29) & E. parvitergum, E.sieboldi \\
Oreochromis mossambicus (28) & E. parvitergum, E.sieboldi \\
Siganus lineatus (55) & Dermoergasilus sp, E.sieboldi, E. parvitergum \\
Tachysurus sp (26) & E. parvitergum, E.sieboldi \\
Terapon jarbua (23) & E. parvitergum, E.sieboldi \\
Triacanthus brevirostris (12) & E.parvitergum \\
\hline
\end{tabular}

*Numbers within brackets indicate the number of fish examined

In Dermoergasilus sp the cephalothorax is twice long as to its width. An antenna is considerably larger in relation to its body length. The second segment of the antenna is equal to the third segment. Antennules are five segmented with fifth partially divided into two. Urosome is half the length of prosome. First abdominal segment is the larger and the last two segments are very small. Egg sac is about half of the body length. Antenule is six segmented. Numbers of setae on segments are 4, 10, 4, 4, 2 and 6 respectively Third segments lay on top of one another to form a complete circle which encircles the primary gill filaments with the help of loose cuticular membrane covering the whole structure except terminal claw.

In parasitized gills, enhanced mucous production, congestion, haemorrhages and primary lamellae erosions were encountered. On the gills, swellings could be seen at or near the site of parasite attachment with a compression of the epithelial cells under the vicinity of the parasite on the free margin of the filament. Attachment resulted in a cavity in gill tissue not only at the point of second antennae insertion but under the entire area occupied by the parasite (Figure 2). The compressed epithelium was noted in having the following features: a lower number of mucous and glandular secretary cells, an increase in infiltrating cells compared to those observed in neighboring filaments, epithelial cells were markedly hypertrophic or hyperplastic. 
Table 2. Prevalence, mean intensity and range of Ergasilus parvitergum infections in different fish species from Batticaloa lagoon.

\begin{tabular}{lccc}
\hline \multirow{2}{*}{ Species of host fish } & \multicolumn{3}{c}{ E. parvitergum } \\
\cline { 2 - 4 } Anabas & Prevalence (\%) & Mean intensity & Range \\
Ambassis gymnocephalus & 60.0 & 6.3 & $0-15$ \\
Chanos chanos & 42.8 & 4.7 & $0-10$ \\
Etroplus suratensis & 59.3 & 8.9 & $0-30$ \\
E. maculatus & 44.1 & 6.4 & $0-25$ \\
Hemirhamphus sp & 27.3 & 3.3 & $0-6$ \\
Leiognathus splendens & 57.9 & 3.0 & $0-4$ \\
Lutjanus sp & 0.3 & 2.7 & $0-6$ \\
Mugil cephalus & 31.3 & 5.2 & $0-11$ \\
Nematalosa nasus & 46.2 & 2.6 & $0-6$ \\
Oreochromis mossambicus & 29.2 & 2.2 & $0-3$ \\
Siganus lineatus & 37.2 & 2.7 & $0-4$ \\
Tachysurus & 5.8 & 9.2 & $0-20$ \\
Terapon jarbua & 72.0 & 10.0 & $0-10$ \\
Triacanthus brevirostris & 16.6 & 3.7 & $0-10$ \\
\hline
\end{tabular}

At the point of second antennae insertion, the lamellar cells were pyknotic and degenerating. The epithelium of neighboring filaments were odematous with a fewer number of infiltrating cells than was observed in the epithelium beneath the parasite.

It was observed that the proliferated epithelium contained hypertrophic epithelial cells with large intercellular spaces in which wandering cells such as lymphocytes, macrophage, blood granulocytes, vacuole cells and coarse eosinophilic granular cells were evident. Remnants of lamellae, with degenerating lamellar cells were seen near the margin of the proliferated epithelium, with degenerating epithelial cells appeared to slough off the surface. 
Table 3. Prevalence, mean intensity and ranges ofDermoergasilus sp, infections in different fish species from Batticaloa lagoon.

\begin{tabular}{lccc}
\hline \multirow{2}{*}{ Species of host fish } & \multicolumn{3}{c}{ Dermoergasilus sp } \\
\cline { 2 - 4 } & Prevalence \% & Mean intensity & Range \\
\hline Anabas & 13.3 & 1.5 & $0-2$ \\
Ambassis gymnocephalus & 0 & 0 & 0 \\
Chanos chanos & 3.6 & 4 & $0-4$ \\
Etroplus suratensis & 4.3 & 3 & $0-4$ \\
E. maculatus & 0 & 0 & 0 \\
Hemirhamphus sp & 0 & 0 & 0 \\
Leiognathus splendens & 0 & 0 & 0 \\
Lutjanus sp & 0 & 0 & 0 \\
Mugil cephalus & 0 & 0 & 0 \\
Nematalosa nasus & 0 & 0 & 0 \\
Oreochromis mossambicus & 0 & 0 & 0 \\
Siganus lineatus & 5.1 & 2 & $0-3$ \\
Tachysurus & 0 & 0 & 0 \\
Terapon jarbua & 0 & 0 & 0 \\
Triacanthus brevirostris & 0 & 0 & 0 \\
\hline
\end{tabular}

\section{Discussion}

Copepods feed by browsing on fish gill epithelium or by ingesting blood from ruptured blood vessels.Ergasilus sp attaches to the gill cartilage by means of antennules, which is spike like and causes bleeding at the time of attachment (Figure 1). The blood expelled from this would be fed by the parasite. Ergasilus sp presumably secrete exogenous digestive enzymes and digestion taken place besides the gill filaments of the host fish. Then subsequently the digested juice was taken inside the gut of the parasite. This was shown by the higher number of cell nuclei within the gut of thErgasilus sp in the gill histological sections. There are some places where the surface of the gill beneath the parasite seems like a cavity which is probably related to the enzymatic action of the gill epithelium beneath the parasite. 
Table 4. Prevalence, mean intensity and ranges of Ergasilus sieboldi for different fish species from Batticaloa lagoon.

\begin{tabular}{lccc}
\hline \multirow{2}{*}{ Species of host fish } & \multicolumn{3}{c}{ E. sieboldi } \\
\cline { 2 - 4 } & Prevalence \% & Mean intensity & Range \\
\hline Anabas & 0 & 0 & 0 \\
Ambassis gymnocephalus & 18.2 & 3.5 & $0-4$ \\
Chanos chanos & 10.7 & 8.7 & $0-15$ \\
Etroplus suratensis & 45.1 & 3.3 & $0-10$ \\
E.maculatus & 17.6 & 2.3 & $0-4$ \\
Hemirhamphus sp & 27.3 & 2.0 & $0-3$ \\
Leiognathus splendens & 15.8 & 2.0 & $0-3$ \\
Lutjanus sp & 9.4 & 2.3 & $0-4$ \\
Mugil cephalus & 31.3 & 2.7 & $0-6$ \\
Nematalosa nasus & 23.1 & 2.3 & $0-3$ \\
Oreochromis mossambicus & 8.3 & 2.0 & $0-2$ \\
Siganus lineatus & 22.0 & 6.7 & $0-15$ \\
Tachysurus & 11.7 & 3.0 & $0-4$ \\
Terapon jarbua & 12.0 & 2.0 & $0-3$ \\
Triacanthus brevirostris & 0 & 0 & 0 \\
\hline
\end{tabular}

(a)

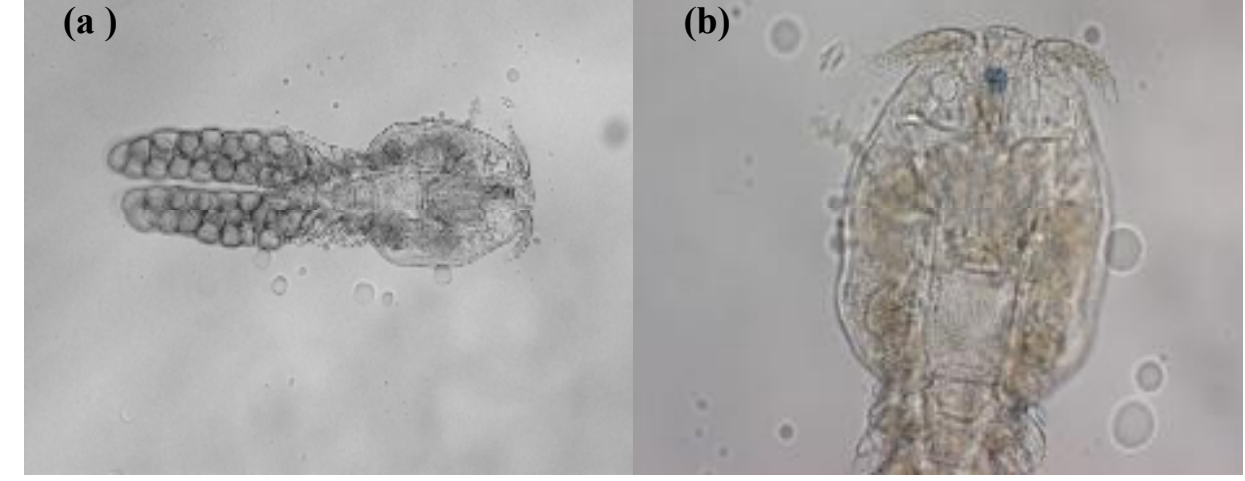

Figure 1. (a) Ergasilus sieboldi extracted from infected fish host x 20. (b) Ergasilus sieboldi enlarged head region x 40 . 


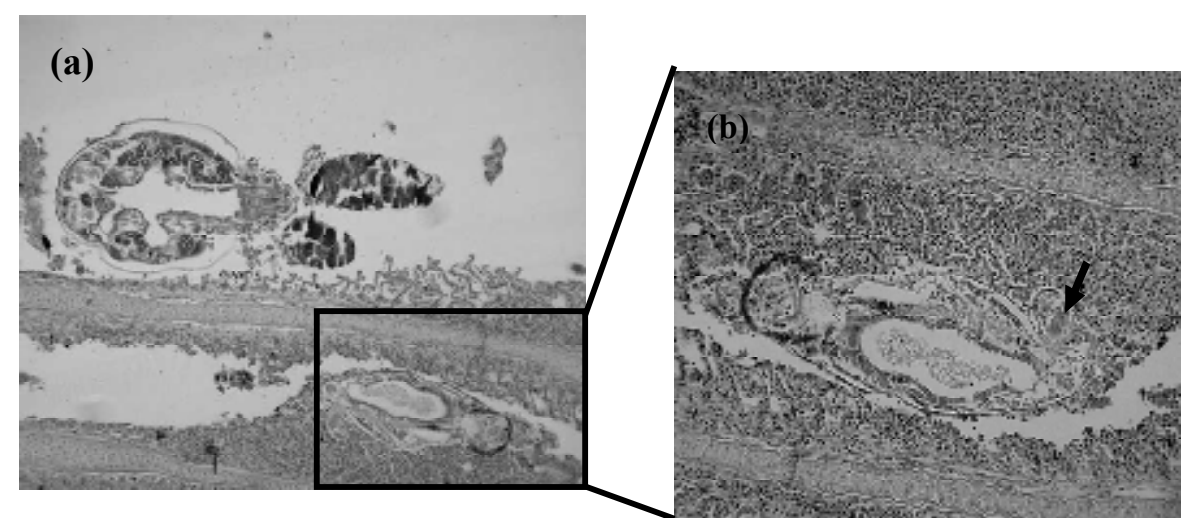

Figure 2. (a) Ergasilus sp. attached to the gill filaments ofSiganus lineatus (X20) (b) A magnified view showing the attachment of the parasite by means of second maxilliped deeply penetrating into gill tissue (arrow) and the fusion of lamellae and severe hyperplasia (X40).

Ergasilus sp attaches to the host using various appendages modified for grasping and this activity can led to secondary infection by pathogenic organisms (e.g. bacteria, fungi, and virus) and causes mass mortality in cultured and wild situation. Secondary gill lamellae showed the development of adhesions between gill filaments and consequently, fish respiration is impaired and reduced feeding pave the ways for weight loss and general deterioration of health. The severity of damage caused by ergasilid infection of fish specimens is directly proportional to the number of copepods on the gills. Accordingly, less than 20Ergasilus sp per gill may have little effect, but, when their intensity increases, where the gill damage may be serious and showed pronounced impact of the histology and lead to mortality. Some pathological effects of ergasilids decrease the body weight, condition factor, osmoregulation or respiratory function of the gills and changed the blood cells differential count which leads to mortality. Mortality of the host fish may occur due to high intensity of infections of E. sieboldi. There was an evidence of an increase in the number of rodlet cells at the site of attachment of an Ergasilus sp. This may constitute an additional confirmation of the defensive role of these cells in the piscine inflammatory system against parasites. At the same time in other fish species, it has been suggested that rodlet cells represent an inflammatory cell type closely linked to other piscine inflammatory cells. Increase or infiltration of different types of cells such as granular cells, lymphocytes, mucous cells at the copepod attachment site on gills of fishes was also reported in this study similar to the studies carried out by Bennet and Bennet (2001); Leino (1996) and Roubal (1999). Rodlet cells represent an inflammatory cell type closely linked to other piscine inflammatory cells. Presence of high numbers of inflammatory cells at the site of Ergasilus sp attachment is related to intense host cellular reaction. 
The histopathology explained in this study for the fish species studied from Batticaloa lagoon is almost similar to the Atlantic salmon infected with Ergasilus labracis that was characterized by severe gill hyperplasia and high levels of mortality (Hogans 1989). Infection of the gills with extremely high numbers of the ergasilid copepods resulted in gill inflammation, necrosis, increase in the mucous production finally lead to death of the hosts.

In conclusion, the major features ofErgasilus sp infections on the gill filaments of the fish studied include destruction of the gill filaments and lamellae exerted by the force of attachment and feeding of the parasite and the resultant hypertrophy of the underlying epithelia reducing the surface area for effective respiration. Gill damage could result in loss of gill surface area for respiration which would lead to suffocation, particularly at high water temperatures. This could also lead to reduced growth and secondary infection affecting the survival of fish The osmoregulatory failure might also be important since the piercing of the parasite exposes the surface of the host to natural environment.. Hence, the histopathological changes induced by the infections of Ergasilus sp would adversely affect the proper functioning of the gills of these infected fish. Mass mortalities of the fish inhabiting in Batticaloa lagoon which occurred during April and May 2004 may be attributed to the infection of gills by these copepods.

\section{Acknowledgement}

Commonwealth Scholarship and Fellowship Commission is acknowledged for the funding to carry out the histopathological work at the Institute of Aquaculture, University of Stirling, UK in $2004-2005$.

\section{References}

Abdelhalim, A. I. 1990.

Morphology and epidemiology of some parasitic copepods (Poecilostomatoida: Ergasilidae) from British freshwater fish. PhD thesis, University of London.

Alston, S. \& J. W. Lewis. 1994.

The ergasilid parasites (Copepoda: Poecilostomatoida) of British freshwater fish, In: Parasitic diseases of fish (A.W. Pike and J. W. Lewis eds), 171-188, Samara Publishing, Tresaith.

Bennet, S. M \& M. B. Bennet. 2001.

Gill pathology caused by infestation of adult and preadultDissonus manteri Kabata (Copepoda: Dissonidae) on coral trout,Plectropomus leopardus (Lacépède) (Serranidae). Journal of Fish Diseases, 24 : 523-533

Dogiel, V .A.; G.K. Petrushevskii,. \& Y . I. Polyanski 1958. 
Parasitology of Fishes. Leningrad University Press (1958) (in Russian, English translation: Oliver \& Boyd, London, 1961)

Ho, J.S. \& T.T. Do. 1982

Two species of Ergasilidae (Copepoda: Pocilostomatoida) parasitic on gills of Mugil cephalus Linnaeus (Pisces: Teleostei), with proposition of new genus Dermoergasilus. Hydrobiologia 89: 247252.

Fryer, G. 1982.

The parasitic Copepoda and Branchiura of British freshwater fishes, a hand book and key. Fresh water Biological Association Science Publication, 6: 1-87.

Hewitt, G. C. 1971.

Two species of Caligus (Copepoda: Caligidae) from Australian waters, with a description of some developmental stages. Pacific Science, 25:145-164.

Hogans, W. E. 1989.

Mortality of cultured Atlantic salmon,Salmo salar L., parr caused by an infection of Ergasilus labracis (Copepoda: Poecilostomatoida) in lower St. Johns River, New Brunswick, Canada. Journal of Fish Diseases, 12: 529-531.

Johnson, S. C. ; R. B. Blaylock, J. Elphick \& K. Hyatt 1996.

Disease caused by the salmon louse Lepeophtheirus salmonis

(Copepoda: Caligidae) in wild sockeye salmon Oncorhynchus nerka) stocks of Alberni Inlet, British Columbia. Canadian Journal of Fisheries and Aquatic Sciences, 53 2888-2897.

Kabata, Z. 1958.

Lernaeocera obtusa n. sp. Its biology and its effect on the haddock. Marine Research Department of Agriculture and Fisheries Scotland, 3: 1-26.

Kabata Z. 1979.

Parasitic Copepoda of British Fishes. British Museum (Natural History) Cromwell Road, London.

Leino, R. L 1996.

Reaction of rodlet cells to a myxosporean infection in kidney of the bluegill, Lepomis macrochirus. Canadian Journal of Zoology, 74: 217-225.

Margolis, L. G.W. Esch,. J.C. Holmes, A.M. Kuris \& G.A. Schad, 1982.

The use of ecological terms in parasitology (Report of an adhoc committee of American Society of Parasitologists). Journal of Parasitology. 68: 131-133.

Motta-Amado, M. A. P. \& C. E. F. Rocha 1995.

Três novas espècies de copepodas parasitas do gênero Ergasilus (Poecilostomatoida,Ergasilidae), copepodas em filamentos branquiais de peixe mugilìdeos do Brasil. Nauplius. 3: 33-48

Neilson, J. D., R. I Perry \& S. P. Valerio, 1987. 
Interactions of caligid ectoparasites and juvenile gadids on Georges Bank, Marine Ecological Progression. Ser. 39:221-232.

Nigrelli, R.F. 1950.

Lymphocystis disease and ergasilid parasites in fishes. Journal of Parasitology, 36: 36

Nilakarawasam, N. \& C. Sommerville 1998.

The parasites of Etroplus suratensis (Bloch) (Pisces: Cichlidae) and their effects on aquaculture management. Sri Lanka Journal of Aquatic Sciences.3: 11-25.

Rahuman, S. \& P. Vinobaba 1999.

Ectoparasites of some commercially important fin fish species of the Batticaloa lagoon, Fifth annual sessions of Sri Lanka Association for Fisheries and Aquatic Resources, 5:12.

Roubal, F. R. 1999.

Extent of gill pathology in the toadfish Tetractenos hamiltoni by Naobranchia variabilis (Copepoda: Naobranchiidae). Diseases in Aquatic Organisms, 35:203-211

White, H. C. 1940.

Sea lice (Lepeophtheirus) and the death of salmon. Journal of Fisheries Research Board Canada 5: 172-175. 
